\title{
Business Continuity and Challenge of Succession in Nigeria: What happens when the CEO leaves?
}

\author{
Dauda, Abdulwaheed \\ Department of Entrepreneurship \& Business Studies, Federal University of Technology Minna, Niger State, \\ Nigeria.
}

\begin{abstract}
Corporate succession planning has attracted considerable interest among management and social science researchers. Most of the research has been conducted in the developed countries and organizations from specific vantage points such as understanding the impact of CEO succession or successor. On balance, there is little research of leadership succession planning in most less developed countries, especially Nigeria. Succession planning is a critical tool for ensuring lasting organizational improvement. However, the biggest challenge for most organizations is how to effect a well-designed change of leadership without disrupting the organizational continuity. This paper asserts that most organizations in Nigeria will be heading for leadership transition crisis unless effective succession planning is urgently integrated into organizational culture. The paper examines what succession planning is about and the challenges associated with its implementations. The paper also reviews the strategies for developing and implementing leadership succession plans. The author used qualitative research methods to investigate leadership succession in Nigeria in both public and private sector organizations. The research reveals that most Nigerian organizations are not engaged in leadership succession planning and implementation. It is also apparent from research findings that for those that tried, the success rate is negligible. The research also revealed other issues such as culture and political complications that are entrenched in most Nigerian organizations, especially those in the public sector. These entrenched issues need to be understood and dealt with to ensure organizational renewal, business continuity and economic growth.

Keywords: succession, continuity, planning, leadership, organizational culture and CEO
\end{abstract}

\section{Introduction}

Successful companies, agencies and organizations have one thing in common, culture of succession management (Walsh \& Seaward, 2006). Corporate leadership succession is of considerable interest among management and social researchers. Most of the research is conducted in developed countries with little attention given to emerging economies such as Nigeria. Corporate leadership succession whether in the public or private sector organizations, is the proactive identifications at all levels of the organization. It differs from leadership replacement, which is the reactive initiative to find a replacement for a retiring or resigning manager. The inability of organizations to have a well-articulated leadership succession plan and culture is capable of leading to disruptions and leadership transition crisis. For instance, sudden death, incapacitation, unplanned resignation or retirement could be disruptive if there is no pool of talents readily available. Similarly, the Board may find itself in a situation where it has irreconcilable differences squabbles with attendant consequences on the organization's performance and image. Furthermore, there may be instance where a large number of employees in the senior and middle management positions could retire within the same period. This would definitely create a huge vacuum and adversely affect performance. Organizations do not have to wait for leadership transition problems/ challenges to manifest before taking steps to ensure continuity of leadership talents. It is therefore imperative to have in place a process that is capable of developing a pool of talents, especially in key operational areas.

\section{Statement of the Problem}

There is little evidence to show that even Nigeria leading organizations undertake succession planning. There was a semblance of succession planning practice in foreign multinationals such as UAC \& Cadbury perhaps due to link to British parent companies. Otherwise unlike some emerging economies that have vibrant public corporations (for example Etisalat, owned by United Arab Emirates (UAE) Telecommunications Corporation); most companies in Nigeria are generally small with poor performance. The major problem is that failure to practice succession planning leads to failure to take advantage of diversity that Nigeria has, as almost all recent public appointments are disputed and sometimes end in courts. Furthermore, it has led to entrenched leadership culture where leaders are not willing to leave office in Nigerian indigenous institutions even when obviously the term of office is stated. Even more disturbing is that the growth of Nigerian institutions remains abysmal as lack of succession planning reduces the scope for leadership development and planning, leading to 
problems of business continuity and growth. The aggregate effect of these problems is failure of business continuity and growth, reducing the effectiveness of Nigerian institutions.

\section{Objectives}

Succession of leadership is a real organizational issue world wide as recent study by a leading executive search and leadership consultants (Crowder et al \& Struggles, along with Stanford University's Center for Corporate Governance, 2001) concluded that CEO succession planning is poor or non-existence in most North American public and private companies. In view of this, report along with the foregoing background. The main objective of this paper is to investigate the corporate succession planning practices of Nigerian organizations and the issues surrounding corporate leadership succession planning and implementation. The researcher sub divided this main objective into the following objectives: To identify the main factors responsible for lack of succession planning in Nigeria To examine and evaluate the effect of failure to practice succession planning in Nigeria as regards business continuity and growth. Finally, to suggest a framework for improved growth and reduce the level of disputes that has followed public appointments in recent decades.

\section{The Concept of Succession Planning}

The concept of succession planning refers to the process where managers identify, assess and develop their staff to ensure that they are capable of assuming key roles in the organization. It is the process of determining key roles within an organization, identifying and assessing possible successors and developing them for present and future opportunities. Succession planning has been defined as "a dynamic, ongoing process of systematically identifying, assessing and developing leadership talent; and assessing, developing and recognizing 'key contributors' to meet future organizational strategic and operational needs" (Gronn, 1996). Succession planning entails identifying top performers in the organization and engaging them to ensure that they are involved and committed to stay for a long period.

\section{Benefits of Succession Planning}

Succession planning is critical to the sustainability and competitive advantage of any organization irrespective of its ownership nature. Thus, succession planning facilitates the organization to take a strategic approach to its leadership development and employee skill assessment. It is particularly important where the Government policy causes massive retirements in order to preserve critical organizational knowledge. According to Collin \& Hussy (2009), succession planning also facilitates a flow of talent emerging from within the organization. This is also capable of boosting the confidence in staff. This point is supported by the findings of Smith et al (2006) observes that succession planning is a tool for talent management in organization, and it is crucial for attracting, keeping, and promoting special talents that helps an organization to remain competitive. "succession planning is widely believed to help business organizations with internal re-sourcing, reduce attrition of the work force caused by job- hopping high-fliers, and prepare qualified candidates for appointment to senior management positions" (Huang, 1999). Successions' planning gives a bigger picture and not just focus on replacing top executives and a good succession plan usually forces organizations to examine all levels of employees and plug talent and skills gaps for the future of the organization.

A well-designed succession gives organizations enough time to offer professional development to the talented employees who are likely to be selected as replacement for those who leave. The main advantage of succession planning in an organization is the active development of a strong 'talent resource' for the future which is vital to attract and retain the best and key people which will help in present and more for the future growth of the organization. Have the right people with right skills in the right jobs doing the right things.

\section{Strategy for Succession Planning}

A comprehensive succession planning strategy encompasses various activities, which provide a roadmap for developing succession plans. There is no right or wrong way to develop a succession plan, hence, different organizations will implement components of any succession planning strategy. Firstly, there must be assessment of key positions in terms of competencies and experiences needed to qualify for leadership positions. Then identify key talents at the top two or three levels in the organization through management assessment of their performance and potential for advancement. Secondly, assess key talents, primary development needs of skills ready for the next level and strategies for potential successors through's formal education, training, leadership and management training, coaching or mentoring and job enrichment. Lastly, monitor implementations of the employee development plans with annual reviews and implementation of transition plan to select leaders from the talent pool to fill the vacancies. Usually there are three succession planning with internal skills, and talent pool planning for training for future successions and replacements (Conger \& Naddler, 2004). 


\section{Models of Succession Planning}

There are mainly three models of succession planning organizations use and these are; a) short-term planning or emergency replacements,

b) long-term planning or managing talent, and

c) combination of above plans.

Firstly, the short-term planning or emergency replacements is the most common model of succession planning and serves as a crucial point for all types of businesses. This model focuses on an urgent need caused by a sudden need to replace departing or lost executive. Secondly, long-term planning or managing talent is based on the strategic frame work for organization's future goals, key positions necessary for growth are identified as well as the best candidates to fill those roles. Some organizations invite all employees to take part in assessment processes, which help identify talent to be developed for the future needs of the organization. Organizations that wish to groom leaders from within their existing talent pool employ talent management as a key component of its long-term human capital strategy. This model has several advantages that include; having a specialized talent pool, defining and building future skills required for the success of the organization, and motivate and retain employees by involvement in internal skills and may be bureaucratic. Thirdly, is the combination model, which combines both plans, allowing senior management to plan for the long-term growth of both the organization and employees within the organization and prepare for emergency replacements to ensure that business is not affected by knowledge loss or lack of skilled employees.

\section{Review of Related Literature}

The current literature on corporate leadership succession emphasizes the strategic importance that organizations need to attach to it. It is imperative that organizations ensure that there is a ready pool of adequately prepared employees who are able to take on higher responsibilities and positions when the need arises. To support this, Charna, Drotter and Noel (2001) argue that organization needs to develop a leadership pipeline to allow for orderly succession of leaders at all levels in the organization. Other researchers like Kets de Vries (1995) and Hill (2005) contend that leadership succession is crucial in enhancing ability of an organization to minimize potential loss of competitive advantage and ensuring business continuity.

There is evidence in literature that for some reasons, leadership succession planning and implementation processes often fail to meet the desired result (Conger and Fulmer, 2003; Conger and Nadler, 2004). Reasons such as failure to invest money, energy and time in people, and entrenchment tendencies on part of the CEO who is reluctant to vacate his or her position contribute to failure of succession planning (Cannella and Shen, 2001; Vancil, 1987; Walsh and Seward, 1990). Another reason for failure of corporate leadership succession planning and implementation is the inherent weaknesses often found in succession models. Take the case of public sector organizations in Nigeria where the geopolitical arrangement of switching top management positions around the zones, irrespective of successor suitability often results in appointing incompetent leaders. Such weakness may hinder smooth transition of the actual succession process, especially the CEO level (ChungHerrara, Enz and Lankau, 2003). However, this is meant not to be the case as geopolitical arrangement to provide needed personnel at short notice. One can overcome some of the deficiencies in generic models by using alternative models that are specific in their treatment within the process of leadership succession planning (Friedman, 2006). The existing literature on corporate leadership succession studies are within the triad; Europe, Asia and USA (Ohmae, 2005) with little information about leadership succession planning and implementation among Nigerian organizations. Our interest is to investigate how these studies could be adapted and implemented within the peculiarity of the Nigerian culture, ethnics and political systems. With this consideration in mind the researcher attempted to examine the HR policies of some Nigerian organizations to learn how they engage or practice corporate succession planning to ensure organizational renewal and business continuity. The study posits that organizational entrenchment exists in Nigerian organizations that are capable of reducing overall effectiveness or leadership succession management. The study also postulates that organizationally generated entrenchment arises from the influence of culture and political environment affecting leadership succession planning and setting up roadblocks to successful transition from one CEO to the next, particularly in government owned corporations and agencies. The presence of ethnic, culture and environmental complexity is not unique to Nigeria, many developed and other developing countries have similar mix, so why should these be tumbling blocks to Nigerian's situation?

Over the decades large amount of literature has been published on several aspects of leadership succession, incorporating the importance of succession management (Rothwell, 2005; Taylor and McGraw, 2004; Huang, 2001), succession rates (Dalton and Dalton, 2007; Brant, Dooley and Iman, 2008), successor origins (Agrawal, Knoeber and Tsoulouhas, 2006) and succession theories (Kesser and Dalton, 1994) to mention a few, we observed that much of the literature concerns with broader issues of leadership succession with little attention to the organization or business strategy. Most literature takes roots deep into Human Resources Management. Yet there is always over concentration on CEO succession instead of succession at all levels 
within the organization of qualified and prepared successors within the organization that will ascend to leadership positions following the departure of those in the top positions (Hambrick and Mason, 2004) or top management team (Smith, Houghton, Hood and Ryman, 2006). Generally top management of senior management team are the ones involved in the strategic vision and direction of an organization. Furthermore, Sobol, M.R; Phil Harkings and Terry Conley (2007) feel that the single most important accomplishment by most admired manager and legendry Chairman and CEO of GE, Jack Welch, was building and integrated system of succession planning. This gave Welch the ability to make wise decisions regarding people as the source of most competitive advantage. Much earlier Huang (2004) stated that most "Japanese top management spend more time thinking about management succession than on anything else". Most successful organizations engage actively in teaching, mentoring and coaching to identify, develop existing talent for future succession. Succession planning is key to business continuity and longevity (James, C. and Jerry P, 1994), the point further emphasized by James Collins (2001) that the best companies groom talented employees for positions of leadership. James Collins (2009) even went further to show that most fallen companies had outside chief executive officers, stating that "leaders who fail the process of succession planning set their companies on a path to decline" (p. 60). Failure to engage in succession planning early on causes organizations to make decisions based on informal judgments, which are often problematic with negative results in most cases. The mismanagement succession planning often arise from a basic assumptions that leadership, as people tend to equate leadership with administratively senor individuals (leithwood, Jantzi, and Steinbanch, 1999). Transformational leaders, rather than transformational leadership, get the greatest attention in leadership research (Gronn 1996). However, distributed leadership, leadership that spreads across organizations without diminishing the importance of the principal's role, is starting to draw more attention (Crowther et al. 2002; Spillane, Halverson, and Diamond 2001). Sustainable, significant improvement depends on understanding and managing this process over time (Hargreaves and Fink 2003). Reformers and change experts rarely grasp the long-team aspects of leadership. Although scholarly research into servant leadership is increasing, those selfless individuals (Dalton, 2007), a lack of specific details persists when examining the definitions and models of servant leadership (Hill, 2005; Hambrick \& Mason 2004; and Vancil; 1997).

One business process which holds potential to reflect the impact of servant leadership is succession planning. It is logical that servant leadership would place emphasis on succession planning with its emphasis on the follower (employee) and the followers' development (Cannella \& Shen, 2006). While virtually all organizations encounter the need for succession planning, research and literature have not focused on the actual process (James, C \& Jerry Porras, 1994). This study provided the opportunity to examine the succession process in a servant -led organization to determine the manner in which the process is involved with servant leadership and its seven constructs (love, humility, altruism, vision, trust, empowerment, and service) that explain the process by which servant leadership behavior manifests itself in the workplace.

\section{Methodology}

In this research, the researcher used two design strategies, emergent design flexibility and purposeful sampling (Patton, 2002). Emergent design flexibility means the researcher was open to adapting inquiry as the understanding of the situation deepened or changed. This strategy allowed the important analysis dimensions to emerge from patterns found in the cases under study without presupposing in advance, what the important dimensions will be, as it is open and flexible. The view of Hill (2003) that emergent design requires the researcher to follow new information as it emerges. Additionally, purposeful sampling was selected because it offers useful manifestations of the phenomenon of interest (Patton, 2002). In this research, the phenomenon of interest was the effect of succession planning and its effects on business continuity. By purposefully selecting a servant-led organization that had gone though a succession, the researcher gained insights and in -depth understanding of the phenomenon of interest. This design strategy also did not try to generalize the data from a sample to a population but merely looked at gaining insight about the phenomenon studied. The data collection for this qualitative study took place during a 4-week period in May 2012 within Nigeria. The researcher made observations and list of Nigerian organizations in two distinct sectors, public and private. The enquiry centered on how top or senior management positions were filled within these two groups of organizations. The researcher made inquiries to find out if formal succession planning took place or head hunting started at the eminent departure of the current Chief Executive.

He then analyzed documents gotten from various sources to obtain an insight into the practice of promotion and top management succession. Documents regarding promotion policies, training programs, evaluation programs, and hiring practice helped to shed light on the succession process of the organization. The research also utilized the general interview guide with leadership and succession planning as the two issue explored. The researcher also conducted interviews using unstructured methods (Easterby-Smith, Thorpe and Lowe, 1991, Lee, 1993) which allowed and exploration of the role leadership played in the succession process without trying to define the role. The research also looked at political issues incorporating geopolitical 
arrangements and affiliations. These additional methods of data collection enable data source triangulation where in the researcher examined all data collected to ascertain whether the themes found in the data remained consistent at different times (Conger and Fulmer, 2003). The researcher employed iterative process to review the data (personal interviews, organizational material, and observations).

\section{Results and Discussion}

The research reveals that most of the world admired states and corporations that have achieved longevity have had chief executives that start planning their departure right at the beginning of their appointment. This seems to make sense because all the CEOs will ultimately come and go, and how they come and go has a profound effect on their corporations, which may largely determine the difference between extended periods of failure and success. In Nigerian organizations, we found that the CEOs have hard times facing and accepting the impending loss of power, a step necessary to plan for their own succession. Some even find delegation difficult as it exposes some deals that need to be covered. As a result, the transitions are not as smooth as they could be. We found cases of unplanned continuity and discontinuity. Discontinuity with the achievements of a leader's immediate predecessor has negative and reversal effect on the progress previously achieved (Hargreaves and Fiunk, 2006). This is true in diverse sectors of Nigerian operational environment, whether in Academic, public sector or private sector. In the private sector however, foreign multinationals do have CEO succession planning and experience less difficulties with replacement. There were also few examples of indigenous organizations with succession planning, for example some Banks in Nigeria. Often innovative leaders left before their innovations take root and their less creative successors abandon their projects and return to status quo. With the experience of what happens elsewhere, the researcher felt that it's time for Nigerian organizations to start being more proactive in succession planning and get serious about it so that Nigerian will benefit from global economic/financial recovery. Here the work of Carey, Ogden and Roland (2000) readily comes to mind. They suggested ten core principles an organization needs to use if it is serious about succession planning. We have summarized these core principles here. Organizations that are serious about succession planning have strong, involved boards, which are professional, understand industry, and are close to their top management team. They encourage "next generation CEO's" to gain exposure to outside board service, to the media and to the investment community. These organizations also form executive committees or operating committees to facilitate the development of several entire organizations. Next, they view succession planning as an ongoing and "real time" process and take as much of the CEO's compensation to the development of succession plans. Finally, they pay their directors increasingly in stocks and require the directors to make a personal investment and periodically calibrate likely internal candidates for CEO against comparable outside leaders and develop succession culture.

In the public sector arena, many parallels could be drawn to create such a best practices checklist for MDAs and universities that should be serious about succession planning. Universities, Polytechnics, COE and MDAs need to have strong, involved trustees, stakeholders and boards that are close to their executives. They should encourage "next generation executives" to gain exposure to outside community and form executive committees or operating committees to facilitate the development of several administrators who are aware of the challenges, business plans, and strategies across the entire institutions. Succession planning should be ongoing and take as much of the CEOs compensation to the development of succession plans and require the trustees or boards to make a personal commitment to the organization or institution and develop succession culture. In all these settings, similar incentives and emphasis could be placed on the preparation of other senior administrative executives such as Vice Chancellors of Universities/Rectors of Polytechnics and Director Generals of MDAs as do CEO of private sector organizations.

Despite the above, the researcher share the feeling of those who feel that several factors strongly militate against a more proactive succession planning, especially in the public sector; the biggest challenge appears to be the geopolitical arrangements that, in most cases, ignore competence or the merit criteria. Another challenger springs from the fact that Government unduly influences appointment into senior management positions, particularly during the democratic dispensation in Nigerian. Sometimes Government policies somersault overnight and this has significant impact on work force requirement of public sector establishments. For instance, in the early 1990's, there was a government circular to MDAs to arbitrary reduce their staff strength by a certain percentage. Again in October 2009, another circular was issued that all Directors who had put in eight years of service as at $31^{\text {st }}$ December, 2009 should be asked to retire, irrespective of the manpower needs and succession plans of those establishments. This would destabilize any system and upturn whatever plans in place. The researcher used one example of this event from an MDA that has staff profile that is heavily skewed to retirement age bracket that would make leadership succession shock is eminent. In this establishment, more than $45 \%$ of the workforce had less than eight years to retire from service and about $50 \%$ of those in senior and middle management positions would retire the same period. In addition, there was no clear recruitment policy, no succession plans as seniority rather than capacity to perform was what determined the next person to 
fill a vacancy. This situation can be replicated to most public sector organizations as government somehow regulates employment.

\section{Conclusion}

The research shows that corporate succession planning is essential for any organization that is to achieve consistent performance. For profit making organizations; this mean survival or collapse. The research reveals that there is an apparent lack of a systematic approach and willingness to recruit, nurture, groom, and retain potential leaders in most institutions in Nigeria. Though succession planning is critical to achieving business sustainability and competitive advantage, organizations in Nigeria do not appear to have well thought out succession plans. Succession planning is important and useful to all types of organizations. The research demonstrates that most public sector organizations in Nigeria have not taken any deliberate efforts toward succession planning. Employees are not nurturing and development for higher responsibilities is none existent as seniority rather than capacity to perform is what determines the next person to fill a job vacancy. Furthermore, before he or she assumes a higher post, there is usually no deliberate training planned for him or her nor is he or she exposed to the demands of the new position. He or she has to grapple with how best to perform the new assignment. The absence of succession planning has resulted in the placement of square pegs in round hole, thus affecting negatively on morale and overall performance. This explains why some establishment, which did well in the past, is almost in extinction now. The leadership transition crisis is compounded by the fact that appointment into top positions are made by the Government usually bases on the geo-political bias. It is sad, because this is a blessing that many countries with experience in managing diversity and inclusion to broaden personnel portfolio, based on objective approach, cases abound when top management exit, the institutions are left without substantive leaders for long periods.

The research also points out that some of these establishments do not have recruitment strategy, hence in some cases; more than $50 \%$ of the workforce are within the same age group and would retire in the next seven years. The consequences of this are obvious; talent and knowledge drain, critical skill gaps, a change in the ethos and dynamics of the business and disruptions. No deliberate attempt has been made to anticipate attrition and deal with it. The researcher also found that these establishments had no retention policies hence no effort is made to gain employee loyalty or commitment. In recent decades, most establishments in the Nigerian public sector have had or experienced and are experiencing leadership succession challenges, which adversely affect organizational renewal. Recall the case of NAFDAC when the previous CEO exited. Because of lack of succession planning, the replacement created a lot of tension and disruptions. The NCC, SEC and BPE are also suffering from leadership succession deficiency is not different in the government is yet to resolve the replacement issues therein. The situation is not different in the educational institutions either. The appointment of Vice Chancellors in most Nigerian Universities has generated a great deal of tension because of lack of leadership succession planning. In a particular case, the transition crisis led to the resignation of the Chairman. The most recent case is the leadership challenges at INEC. The private sector organizations are also grappling with leadership transition challenges. Apart from Guarantee Trust Bank Plc that has a developed leadership succession plans, leadership change in the some banks involved regulatory authorities.

\section{Recommendations}

Despite the benefits of succession planning, most organizations do not practice succession planning. Replacement of disengaged staff is not done in a systematic manner. To reposition organization for effective performance and service delivery, there is the urgent need for organizations to establish effective succession planning capable of building a pool of talents from within. This will enhance leadership continuity, values, and ethos of the business. It will also facilitate the development of a strong 'talent resource' for the future which is vital to attract and retain the best and key people which will help in present and more for the future growth of the organization. Have the right people with right skills in the right jobs doing the right things. The key is to match the needs of the organization to the goals of the individual.

Very critical to the succession planning process is a retention strategy that will not only motivate employees, but also build up their commitment to the organization. Keeping talented people in place by providing them with opportunities they may not receive elsewhere will create a stronger and more loyal group of future managers and executives thus saving the company's recruiting and hiring costs over the long-term. One way to ensure a successful leadership transition is to build a culture of strong leadership whereby employees show effective leadership at all levels. Strengthening leadership capacity throughout the organization can enable a highly successful transition by reducing dependency on a single individual, such as a certain senior leader or key person. Succession planning in the public sector organizations is inhibited by such factors as politically motivated geo-political arrangements, inconsistency and policy upheavals, "sit tight" attitude of leader. These factors can be overcome if organizational renewal and continuity become the goal priority of leadership in the country. 


\section{References}

[1] Agrarwal, A.; Knoeber, C. R. \& Tsoulouhas (2006). Are outsiders handicapped in CEO sucessions? Journal of Corporate Finance. 12(3). 619-644

[2] Brant,j.; Dooley, r. \& Iman, S. (2008). Leadership Succession: an approach to filling the pipeline, Strategic HR Review, 7(4), 17-24.

[3] Cannella, A.; \& Shen, w. (2001) So close and yet so far: Promotion versus exit for ceo heirs apparent. Academy of Management Journal, 40(2), 252-270.

[4] Carey, D. C, Ogden, D. \& Roland, J.A. (2000). CEO Succession: A window on how boards can get it right when choosing a new chief Executive. New York, Oxford University Press

[5] Charan, R., Drotter, s. \& Noel, J. (2001). The Leadership Pipeline: how to build the leadership powered company. San Francisco, Jossey=Bass.

[6] Chung-Herrera,B. g,, Enez, C.A. \& Lankau, M.j. (2003). Groooming future hospitality leaders: A competencies model, cornell hotel and REStaurant Administration Wuarterly, 44(3), 17-25

[7] Collines,J. (2001). Good to Great: Why Some Companies Make the leap and others Don't. New York, HarperBusiness.

[8] Collines, j. (2009). How the mIghty Fall: And Why Some Companies Never Give I, New York, Collins Collins,J.C, \& Porras,J.I. (1994). Built to Last. New York, Harper Business.

R. (2009). Business research, Basingstoke, Palgrave Macmillan Collis, J, \& Hussey, Developing your leadership pipeline. Harvard Business Review, 81 (12), 76-86

Conger, J.A. \& Fulmer, R, M. (2003).

[9] Conger, J.A,, \& Nadler, D.A. (2004). When CEOs step up to fail. MIT Sloan Management Review, 45(3), 50-50

[10] Crowther, F. S; Kaagan, M, Ferguson; and L, Hann, (2002). Developing teacher leaders; How teacher leadership enhances school success. Thousand Oaks, CA; Corwin Press.

[11] Dalton, D, R, \& Dalton, C.M. (2007). CEO Succession; the times they are a -changing',journal of business Strategy. 28(1), 5-7

[12] Drucker, P.F. (1980). Managing in Turbulent Times. New York, Harper \& Row

[13] Easterby-Smith, M, Thorpe, R. \& Lowe, A. (1991). Management Research; An introduction london, Sage.

[14] Friedman, S. D. (1996). Succession systems in large corporations; Characteristics and correlates of performance, Human Resource Management, 25(2), 351-367

[15] Gronn, P. (1996). From transactions to transformations; A new world order in the study of leadership. Educational Management and Administration 24(1); 7-30

[16] Hambrick, D.C, \& Mason,P.A,(1984) Upper echelons; the organisation as a reflection of its top managers, Acade,u pf amage,emt Review. 9(2), 193-206

[17] Hargreaves, A, \& Fink, D, (2006) Sustainable Leadership San Francisco, Jossey-B;

[18] Hargreaves, A \& Fink, D (2003). Sustainable Leadership, Phi Delta kappan 84(9):693-700

[19] Hill, G. C. (2005). The effects of managerial succession on organisational lperformance. Journal of Public Administration Research and Theory $15(4), 585-597$

[20] Huang, T. C. (2004). Succession management systems and human resource outcomes. International Journal of Manpower, 22(7), 736-747

[21] Kesser, I. F, \& Dalton, D. R. (1994) top Management turnover and CEO succession, An investigation of the effect of turnover on performance. Journal of Management Studies, 31(5), 701-713

[22] Kets de vriaes, (1995). The fast track factor; Develping tomorrow's directors, Director, 49(5), 44-47 Lee, M. (1993) Doing Research on Sensitive Topics, London, Sage.

[23] Leithwood, K. D.; Jantzi, and R, Steinbach, (1999), Changing leadership for changing times, Buckingham, England; Open University Press.

[24] Manz, C. C.; \& Sims, H.P. (2001). the new superleader; leaders other to lead themselves. San Francisco; Berrett-Koehler.

[25] National Clearinghouse for Comprehensive School Reform, (2002), Planning for the succession of leadership. NCCSR Bookmark, 3(8), www.goodschools. Gwu.edu/pubs/book/augo2.html.

[26] Ohmae,K. (2005) the Coming of Global competition, New York, Free Press

[27] Patton,M.Q (2002). Qualitative research \& evaluation methods. London: Sage

[28] Rothwell, W.J. (2005). Effective succession planning ; Ensuring leadership continuity and building talent from within. New York; AMACON. $\quad$ Smith, A.; Houghton, S. M; Hood, J, N, \& Rayman, J, a (2006) Power relationships among top managers; Does top management team power distribution matter for organisational performance? Journal of Business research, 59(5), 622-629

[29] Sobol, M, R; Harkins, P. \& Colney, T,; Eds(2007) Linkage Inc,'s Best Practices for Succession Planning. San Francisco, John Wiley $\&$ Sons, Inc.

[30] Taylor, T.; \& McGraw, P. (2004) Succession Management practices in Australian organisations. International Journal of Manpower,25(8), 781-758

[31] Vancil, R. (1997) passing the Baton; Managing the process of CEO succession Boston, MA: Harvard University Press.

[32] Walsh, J.P. and Seward, J.K. (2000) on the efficiency of internal and external corporate control mechanisms. Academy of Management Review, 15(3), 421-458 